\title{
The value of public labour market information and the stability of the market
}

Citation for published version (APA):

Borghans, L. (1990). The value of public labour market information and the stability of the market. Researchcentrum voor Onderwijs en Arbeidsmarkt, Faculteit der Economische Wetenschappen. ROA Working Papers No. 6E https://doi.org/10.26481/umarow.199006E

Document status and date:

Published: 01/01/1990

DOI:

10.26481/umarow.199006E

Document Version:

Publisher's PDF, also known as Version of record

\section{Please check the document version of this publication:}

- A submitted manuscript is the version of the article upon submission and before peer-review. There can be important differences between the submitted version and the official published version of record.

People interested in the research are advised to contact the author for the final version of the publication, or visit the DOI to the publisher's website.

- The final author version and the galley proof are versions of the publication after peer review.

- The final published version features the final layout of the paper including the volume, issue and page numbers.

Link to publication

\footnotetext{
General rights rights.

- You may freely distribute the URL identifying the publication in the public portal. please follow below link for the End User Agreement:

www.umlib.nl/taverne-license

Take down policy

If you believe that this document breaches copyright please contact us at:

repository@maastrichtuniversity.nl

providing details and we will investigate your claim.
}

Copyright and moral rights for the publications made accessible in the public portal are retained by the authors and/or other copyright owners and it is a condition of accessing publications that users recognise and abide by the legal requirements associated with these

- Users may download and print one copy of any publication from the public portal for the purpose of private study or research.

- You may not further distribute the material or use it for any profit-making activity or commercial gain

If the publication is distributed under the terms of Article $25 \mathrm{fa}$ of the Dutch Copyright Act, indicated by the "Taverne" license above, 
THE VALUE OF PUBLIC LABOUR MARKET

INFORMATION AND THE STABILITY

OF THE MARKET

ROA-W-1990/6E

Lex Borghans

RESEARCH CENTRE FOR EDUCATION AND LABOUR MARKET

Faculty of Economic Sciences

Rijksuniversiteit Limburg

Maastricht, November 1990 


\section{Borghans, Lex}

The value of public labour market information and the stability of the market / Lex Borghans. Maastricht: Research Centre for Education and Labour Market, Faculty of Economic Sciences, Rijksuniversiteit Limburg.- (Werkdocument $=$ Working Paper / Researchcentrum voor Onderwijs en Arbeidsmarkt, ISSN 0922-4645; 1990/6E) Met lit. opg.

ISBN 90-5321-042-3 in spiraalband

SISO 318.7 UDC $371: 331.5$

Trefw.: onderwijs en arbeidsmarkt; onderzoek. 


\section{CONTENTS}

1. INTRODUCTION 1

2. STABILISATION 4

3. THE VALUE OF PREDICTIONS: STABILISATION AND ALLOCATION 9

4. INFORMATION VERSUS INTERPRETATION FORECAST ERRORS

5. THE VALUE OF PUBLIC FORECASTS: TWO EMPERICAL EXAMPLES

6. CONCLUSIONS 


\section{ABSTRACT}

Education as investment in human capital is a typical example of a good for which no futures market exists. The absence of such a market leads to an allocation problem which might be reduced by the provision of information by a public forecasting bureau. Passing over the reasons for the absence of a human capital futures market, this paper investigates the welfare effects of public labour market information on the allocation of human capital.

In the seventies some articles appeared about the value of public information, which were based on surplus-calculations with respect to stabilisation policies. Although these stabilisation theories itself have become old-fashioned, their link to public prediction problems is, however, still relevant. The existing literature about this link is erroneous or incomplete. Therefore, this paper gives a reconstruction of the calculations of the value of public information, especially with respect to the labour market. The welfare effects of information and interpretation errors will be discerned into stabilisation and allocation effects and their distribution between employers and students/workers will be given. Finally two empirical illustrations are given.

I would like to thank Jaap van Dam, Paul Ghijsen, Hans Heijke, Peet van de Loo, Hans Maks and Arjan van Witteloostuijn for their helpful comments. 


\section{INTRODUCTION}

Educational investments often have to be made several years before the human capital can be used at the labour market. This delay gives rise to an allocation problem, since the situation at the labour market in the future is not known. For many goods which require such an early investment, futures markets exist in order to use optimally the available relevant information about the future situation or investment decisions are made by specialists, i.e. managers who are trained and selected to anticipate future developments. For education, however, neither such a futures market does exist, nor can students be expected to be specialists in investment decisions. Such an absence raises the question whether it is possible to create alternative structures to improve the allocation process. Without looking for reasons for this non-existence of a futures labour market, this paper investigates the effects of a public forecast that aims at improvement of the match between education and labour market.

In their famous paper, Grunberg and Modigliani (1954) have shown the possibility of a correct public forecast. Although a public forecast will change the expectations of future events of human beings, and will therefore change their actions, it is still, theoretically, possible to provide a public forecast that does not falsify itself. Grunberg and Modigliani base their existence-proof on a fixed-point argument, i.e. a correct public forecast has to be based on those presumed actions which will be chosen by the human beings, after they know the public forecast.

The possibility of a correct public forecast does, however, not imply its desirability. In a situation in which a public forecast is available, people will react to this prediction, what might influence their situation, but also other people's situation. Grunberg and Modigliani give an example of a situation in which the provision of a public forecast has such welfare effects. 'In the absence of public prediction, suppliers were found to act on the basis of unwarranted price expectations, so that they bring to the market a quantity which either falls short of or exceeds what can be sold at the expected price. Consequently, there is a misallocation of resources. If the market price is higher than the expected price, not enough resources have been allocated to this particular industry (and too much to other industries) and conversely. If, on the other hand, correct public prediction is made, suppliers will make their decisions on the basis of warranted price expectations, and no misallocation of the resources used in the industry occurs. By making available to the suppliers relevant information previously unknown to them, the public prediction causes an improved allocation of the resources used in the economy. ${ }^{1}$

1. Grunberg and Modigliani (1954), p. 476. 
In the seventies and in the early eighties some studies appeared which investigated these welfare effects of public price predictions by a calculation of changes in consumer and producer surplus. ${ }^{2}$ In most of this literature the welfare effects of public predictions have been related to the welfare effects of price stabilisation. ${ }^{3}$ Studies about the welfare effects of price stabilisation ${ }^{4}$ were based on the comparison of a situation of no public intervention in which demand or supply fluctuate in time with a situation in which the government intervenes, e.g. by introducing a kind of buffer stock, in a way such that supply and demand equal the long term equilibrium situation. Analogously, the study of the welfare effect of a public prediction might be based on a comparison of a situation in which supply or demand differ from equilibrium due to prediction errors with a situation in which supply and demand are 'constant' because of the availability of the correct public forecast. Variation in time is replaced by probabilistic variation due to forecast errors.

In the theory of price stabilisation new elements, like rational expectations and futures markets, have come to the attention, ${ }^{5}$ which pushed away the theory based on surplus calculations. However, for a study about the value of information of public labour market information the surplus model is still useful. Firstly, it seems not reasonable to presume rational expectations in this context, since the reason of interest in public predictions is the notion that students are not able to form predictions that are enough accurate. Students are no professionals in investment decisions. Secondly, at the labour market there is no such thing as a futures market. ${ }^{6}$ Although labour also is not storable, and thus the stabilisation model makes no sense on its own in the context of educational choices, the link between the value of public predictions and stabilisation policy remains (conceptually) valuable.

The aim of this paper is to reconstruct the literature concerning the value of public predictions, with a special regard to the labour market. The existing literature on this subject is incomplete and contains some errors, so a reconstruction of the ideas and a recalculation of the formulas might take away several misunderstandings.

2. E.g. Freebairn (1976), Turnovski (1978), Freebairn and Withers (1979), and Antonovitz and Roe (1986).

3. See e.g. Smyth (1973), Turnovsky (1974), and Devletoglou (1961).

4. E.g. Waugh (1944), Oi (1961), Massel (1969), and Turnovski (1978).

5. E.g. Turnovski (1979), Campbell and Turnovski (1985), and Weller and Yano (1987).

6. Institutions like the internal labour market have a similar function, but they are not relevant for full-time students. 
The calculations of this paper will be based upon a hypothetical market at which students have to make a certain educational choice, which completely determines their labour market segment several years later as they finish school, i.e. there is specific education, directed at one unique segment without switching opportunities. Firstly, the welfare effects of price stabilisation based on surplus calculations, will be presented (section 2). Secondly, the link between stabilisation and public predictions will be taken into account. Besides the stabilisation effect an allocation effect will be introduced to explain the value of a public prediction (section 3 ). In the fourth section two different kinds of prediction problems will be distinguished, an interpretation error and an information error, which have a different impact on the value of information. Finally, an empirical example will be given, which is a recalculation of the example of Freebairn and Withers (1979).

In this paper the welfare costs are calculated, compared to a situation in which government completely stabilises wages and provides exact forecasts. The possibility for government to do this, is left out the discussion. The full-information position of government only serves as a hypothetical bench-mark. 


\section{STABILISATION}

The question whether government should stabilise prices has been a point of contention for a long time. Advocates of stabilisation policy stressed the fact that the market should be transparent in order to make optimal allocation decisions possible. Prices that vary too much will make many economic consequences very uncertain, and will make people make the wrong decisions. Opponents stressed the importance of free markets without any governmental intervention in order to get an optimal allocation process. In 1944 Waugh wrote a remarkable article in which he showed that consumers gained more from instable prices than from stable prices. In $1961 \mathrm{Oi}$ demonstrated that producers gain from fluctuations in demand, and thus from price instability. Since high prices and high demand coincide, producers will gain more from a raise in prices than they lose in a situation of low demand and low prices.

A naive combination of Oi's and Waugh's results would lead to the conclusion that both consumers and producers gain from price instability. The incorrectness of this conclusion, however, has been shown by Massel (1969). Waugh and Oi do not take into account the same type of price instability. While Waugh's price instability is caused by a changing supply function, Oi's instability is caused by changes in the demand function.

Massel takes into account both types of instability. His basic model of a partial equilibrium consists of the following equations:

(1) $S=C_{s}+X_{s}+\beta_{s} w$

(2) $D=C_{D}+X_{D}+\beta_{D} w$

(3) $S^{e q}=D^{e q}$

in which $\beta_{s} \geq 0, \beta_{D}<0$

Equation (1) is the supply function, which relates the supply of a certain type of labour $(S)$ to the wage $(w) . X_{S}$ is a random variable with expectation 0 and variance $\sigma_{s}^{2}$, which denotes the changes in the underlying utility-functions that cause changes in the supply. Shifts in the supply function are only allowed to be parallel. It is also possible to allow for changes in the slope of the curve, but Massel $(1969)^{7}$ shows that this does not lead to qualitative different conclusions, while it does lead to more complex calculations. Equation (2) is the demandfunction for labour $(D)$. It also contains a random part, $X_{D}$, with expectation 0 and variance $\sigma_{D}^{2}$, which represents changes in the profit-function, caused by, e.g., changes in prices on other

7. Massel (1969), note nr. 9. 
markets or by technological innovation. The linearity of the supply and demand function reflects an implicit assumption about the distribution of preferences and production functions. This linearity is used to get analytical results.

Solving the model gives an equilibrium wage and an equilibrium amount of labour:

(4) $w^{e q}=\frac{C_{D}+X_{D}-C_{S}-X_{S}}{\beta_{S}-\beta_{D}}$

(5) $S^{e q}=D^{e q}=\frac{\beta_{S}}{\beta_{S}-\beta_{D}}\left(C_{D}+X_{D}\right)+\frac{-\beta_{D}}{\beta_{S}-\beta_{D}}\left(C_{S}+X_{S}\right)$

and a random shift affects the equilibrium wage and equilibrium amount of labour as:

(6) $\Delta w^{e q}=\frac{1}{\beta_{s}-\beta_{D}} X_{D}$

(7) $\Delta w^{e q}=\frac{-1}{\beta_{s}-\beta_{D}} X_{S}$

(8) $\Delta S^{\text {eq }}=\frac{\beta_{S}}{\beta_{S}-\beta_{D}} X_{D}$

(9) $\Delta S^{e q}=\frac{-\beta_{D}}{\beta_{S}-\beta_{D}} X_{S}$

Figure 1: Welfare effects due to a shift in demand for students (a) and employers (b)

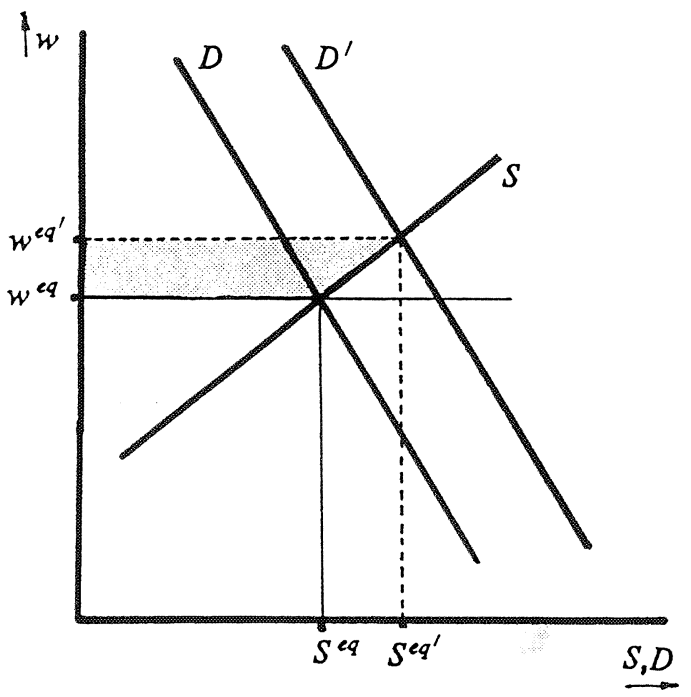

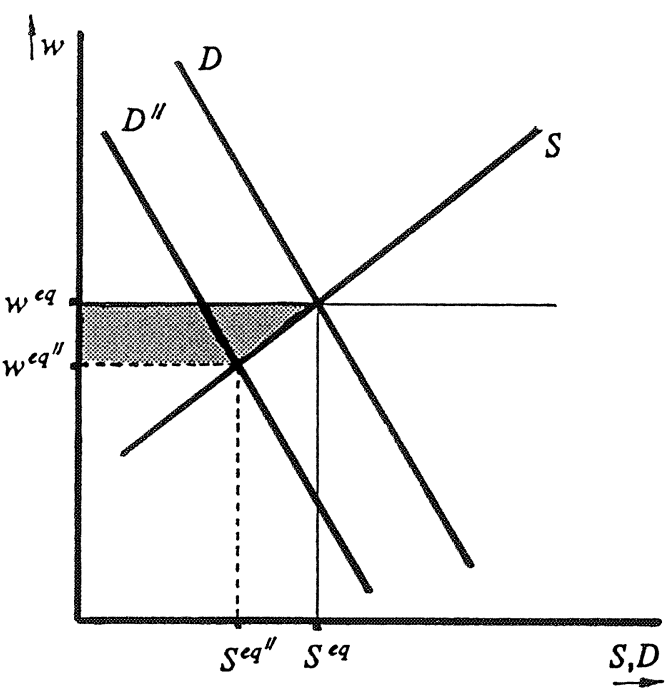


Figure 1 shows the partial welfare-effects of a shift in the demand function, using the surplusvalues as a measure of the welfare-effect. Government might, by some imaginary kind of buffer-stock policy (imaginary, because labour can not be stored) keep the wages equal to the long term equilibrium (the expected wage). If the wage is above the normal level, students will earn this higher wage, but also more students will enter. If the wage is below normal level students will earn less, but also their number will decrease, making the loss in case of a pricefall less than the gain of an equal price-raise. Therefore the expected welfare effect of instability is positive. This difference in expected welfare, compared to the stabilised situation will be called the welfare-gain for students of demand instability:

$$
\begin{aligned}
W_{S t}\left(0, \sigma_{D}^{2}\right) & =\int_{-\infty}^{\infty} \frac{1}{2} \Delta w^{e q}\left(S^{e q}+S^{e q}+\Delta S^{e q}\right) \mathrm{d} F_{D}\left(X_{D}\right) \\
& =\int_{-\infty}^{\infty}\left[\frac{1}{\beta_{S}-\beta_{D}} S^{e q} X_{D}+\frac{1}{2} \frac{\beta_{S}}{\left(\beta_{S}-\beta_{D}\right)^{2}} X_{D}^{2}\right] \mathrm{d} F_{D}\left(X_{D}\right) \\
& =\frac{1}{2} \frac{\beta_{S}}{\left(\beta_{S}-\beta_{D}\right)^{2}} \sigma_{D}^{2}>0
\end{aligned}
$$

The part of the equation in which $X_{D}$ appears in the first moment is equal to zero, because its expectation is equal to zero. This welfare gain is positive, so a public stabilisation will have the inverse, and therefore a negative effect on welfare. This is similar to the results of Waugh (1944) and Oi (1961).

Figure 2: Welfare effects due to a shift in supply for students (a) and employers (b)

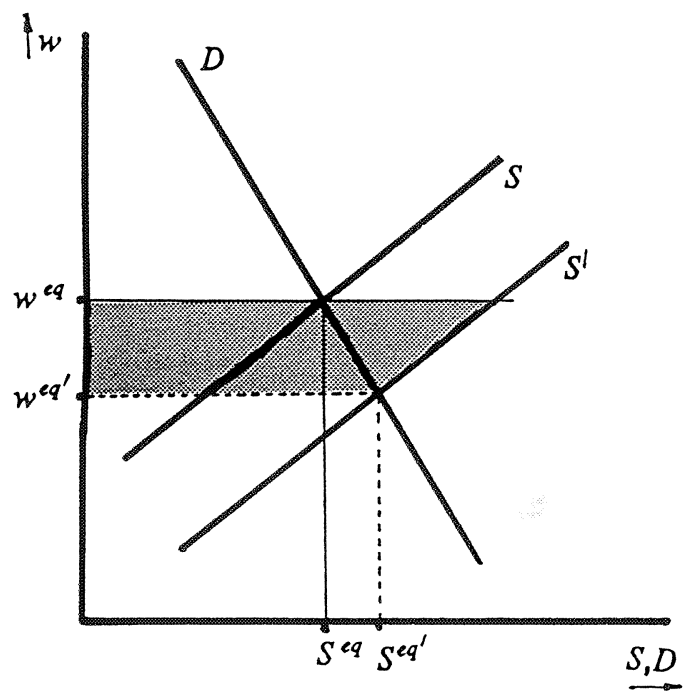

b

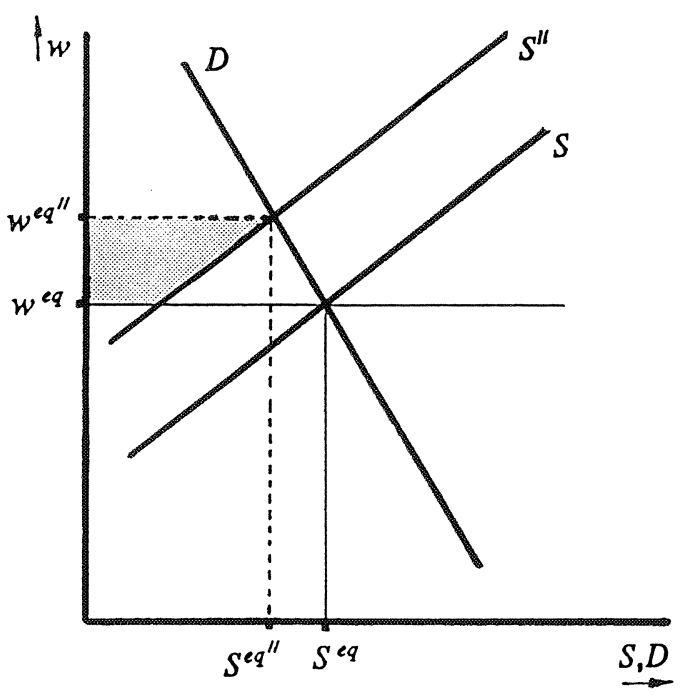


Similarly, the gains of an unstable supply function can be derived. Figure 2 illustrates this welfare effect. If the supply function moves to the right, students will, compared to the case in which the government keeps wages equal to the long-term equilibrium lose a part of this equilibrium wage while many students will enter the market. In the case of a shift to the left a small amount of students will get a higher wage, so unstability will make students worse off:

$$
\begin{aligned}
W_{S t}\left(\sigma_{S}^{2}, 0\right) & =\int_{-\infty}^{\infty} \frac{1}{2} \Delta W^{e q}\left(S^{e q}+\Delta S^{e q}+S^{e q}+X_{S}\right) \mathrm{d} F_{S}\left(X_{S}\right) \\
& =\int_{-\infty}^{\infty} \frac{1}{2} \frac{-1}{\beta_{S}-\beta_{D}}\left(2 S^{e q}+\left(\frac{-\beta_{D}}{\beta_{S}-\beta_{D}}+1\right) X_{S}\right) \mathrm{d} F_{S}\left(X_{S}\right) \\
& =\frac{1}{2} \frac{2 \beta_{D}-\beta_{S}}{\left(\beta_{S}-\beta_{D}\right)^{2}} \sigma_{S}^{2}<0
\end{aligned}
$$

In expectation the welfare gain from fluctuations in the supply function is negative.

Similar results can be derived for producers' welfare. Adding up both sources of instability gives the total welfare costs of price-instability: ${ }^{8}$

(10) $W_{S t}\left(\sigma_{S,}^{2} \sigma_{D}^{2}\right)=\frac{\left(2 \beta_{D}-\beta_{S}\right) \sigma_{S}^{2}+\beta_{S} \sigma_{D}^{2}}{2\left(\beta_{S}-\beta_{D}\right)^{2}}<0$

(11) $W_{E m p}\left(\sigma_{S}^{2}, \sigma_{D}^{2}\right)=\frac{\left(\beta_{D}-2 \beta_{S}\right) \sigma_{D}^{2}-\beta_{D} \sigma_{S}^{2}}{2\left(\beta_{S}-\beta_{D}\right)^{2}}<0$

(12) $W_{T}\left(\sigma_{S}^{2}, \sigma_{D}^{2}\right)=-\frac{\sigma_{S}^{2}+\sigma_{D}^{2}}{2\left(\beta_{S}-\beta_{D}\right)}<0$

(13) $\sigma_{w}^{2}\left(\sigma_{S}^{2}, \sigma_{D}^{2}\right)=\frac{\sigma_{S}^{2}+\sigma_{D}^{2}}{\left(\beta_{S}-\beta_{D}\right)^{2}}$

Equation (13) gives the wage-variance that is related to the two sources of instability. While the welfare gains for students and employers might be both positive or negative, depending on the ratio of the two sources of instability and the parameters of the supply and demand function, in total (equation (12)) there always is a welfare loss due to instability. This completely fits to the intuition of Samuelson (1972) who, without giving proper arguments, criticises Waugh (1944), because of the impossibility of a Santa Claus. If instability would be desirable, extra instability

8. Massel (1969), p. 292. 
could be introduced, making everyone better off. Samuelson stresses that somebody has to pay these gains.

This theory of the welfare effects of price stabilisation has not been without critique. One of the main points against the theory is that if the government is able to keep a buffer in order to stabilise the market, entrepreneurs also will be able to do so. Buffering, in fact is a technology which makes it possible to transform a product in a certain year into the same product in another year. Since this transformation will be profitable, there is no need for the government to do so. The market system will, by arbitrage, stabilise the market itself.

If, on the other hand, it is not possible to keep goods in buffer, as is the case with labour, this will also be impossible for the government. Keeping wages constant will become a difficult and costly affair, which costs are not taken into account in the model.

A second objection against the model is that it does not incorporate one of the essential aspects which makes stabilising important. Stabilisation has been seen as desirable, because it makes the market more transparent. A stable price makes it more easy for people to predict the prices, which enables them to allocate more accurately. This, in fact, is an informational aspect, which does not appear in the model. Predictions do not appear in the model.

In accordance with these two points of critique the theory of price stability has been extended with the study of futures markets. ${ }^{9}$ At futures markets the relation between the price of a certain product in different years is explicitly taken into account, and futures prices can be seen as mechanisms to optimise the accuracy of price predictions.

For the study of the value of public information in regard of the relation between educational choice and the labour market, the simple welfare model has, however, not lost its interest. Although labour is non-storable, government might try to stabilise wages by the provision of wage forecasts. At the labour market there is no such a thing as a futures market, by which the need for information can be fulfilled.

Several studies have shown the link between public price stabilisation and public price forecasts. Unfortunately, they contain some errors, are incomplete or have not been expressed clearly. Next two sections the welfare effects of public forecasts will be reexamined.

9. E.g. Turnovsky (1979). 


\section{THE VALUE OF PREDICTIONS: STABILISATION AND ALLOCATION}

Price instability in last section was caused by stochastic changes in the supply and demand function. Another cause of price instability is the existence of forecast errors.

Since schooling often takes several years a student has do decide which course he will take several years in advance. To simplify the problem, the assumption is made that the choice of a course completely determines the type of job that can be fulfilled afterwards, i.e. there is no possibility to adjust later on to new circumstances. At the moment the student has to choose, wages at the moment he will enter the labour market are not known, since there exists no futures labour market. The best thing a student can do is to base his decision on a prediction of that future wage and a prediction might, of course, contain an error. Similar models can be found in Freebairn (1976), Turnovski (1978) and Freebairn and Withers (1979).

Prediction errors can be viewed upon with respect to the equilibrium wage, i.e. the wage that would prevail if no information problem occurred (if prediction is equal to realisation), or with respect to the realised wage. In this paper the first approach is chosen.

Figure 3: Welfare effects for students in case of an overprediction (a) and underprediction (b).

a

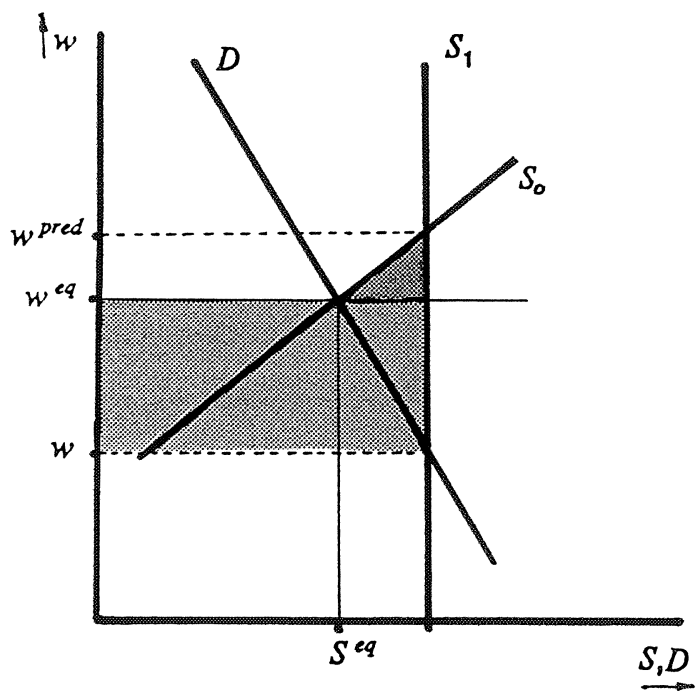

b

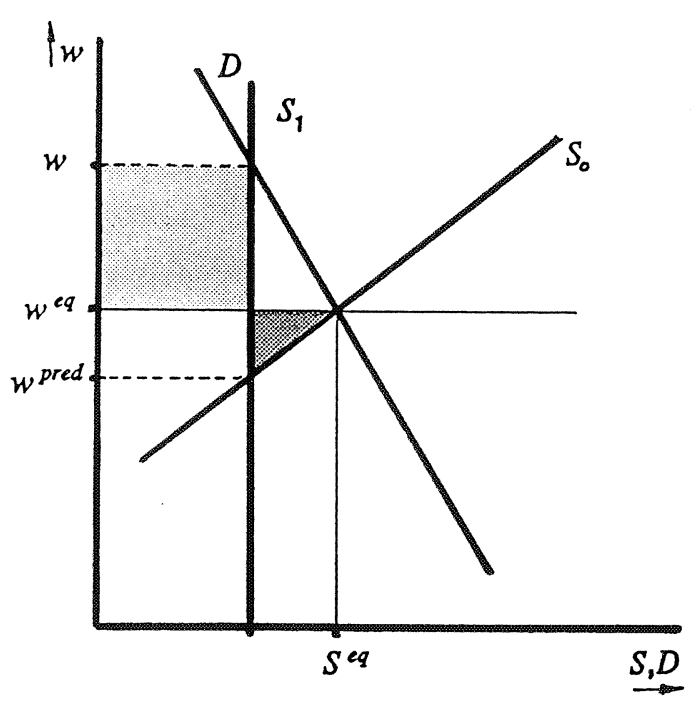

Welfare gain due to instability Welfare loss due to instability

Welfare loss due to allocation problems

Figure 3 shows what will happen in case of a prediction error. In figure $3 a$ the predicted wage is too high. Therefore, too many students will choose this particular course and after several 
years too many students will enter this segment of the labour market. Since at this moment students can not switch anymore, the short term supply function $\left(S_{1}\right)$ is completely inelastic. The counterpart is illustrated in figure $3 \mathrm{~b}$. The prediction is too low, therefore too few students decide to enter, so the short term supply function shifts to the left.

Due to the prediction error the short term supply function fluctuates around the equilibrium, analogous to the stability problem in previous section. There is, however, a difference between the stability problem and the prediction error problem. In case of an over-prediction, some students will enter the market who would not even have entered in the case they had known to get the equilibrium wage. These students do not only lose money because the wage decreased, but also because their reservation wage is above the equilibrium wage. In case of an underprediction, some students do not enter which would have entered if they had known the equilibrium wage. These cases are indicated in the figure with a black triangle. In the case the prediction error disappears, not only the wage becomes equal to the equilibrium wage, but also some students will make a better match which induces an extra gain besides the stabilisation gain. Better prediction will thus provide welfare gains to students, due to stabilisation effects and due to allocation effects. If the assumption is made that the prediction error $\Delta w^{\text {pred }}$ has a zero expectation and variance $\sigma_{w}^{2}$, the allocation welfare effect of forecast errors can be calculated as:

$$
\begin{aligned}
W_{S t}^{\text {all }}\left(\sigma_{w}^{2}\right) & =\int_{-\infty}^{\infty}-\frac{1}{2} \Delta w^{\text {pred }} \Delta S_{1}^{e q} \mathrm{~d} \Delta w^{\text {pred }} \\
& =\int_{-\infty}^{\infty}-\frac{1}{2} \beta_{s} \Delta w^{\text {pred } 2} \mathrm{~d} \Delta w^{\text {pred }} \\
& =-\frac{1}{2} \beta_{s} \sigma_{w}^{2}
\end{aligned}
$$

From the employers point of view this allocation argument plays no role. To them it does not matter whether a student enters the market mistakenly or not. So, from the employers point of view the situation is exactly the same as in the case of unstable supply and demand functions:

(15) $W_{E m p}^{a l l}\left(\sigma_{w}^{2}\right)=0$ 


\section{INFORMATION VERSUS INTERPRETATION FORECAST ERRORS}

In the previous section it has been shown that the welfare effect of a forecast error can be split up into the welfare effect of stabilisation and the allocation welfare effect. The allocation welfare effect has been calculated, but the precise relation between the prediction error problem and stabilisation problem has been omitted. In this section this stabilisation effect will be fitted into the model of section 2 . The nature of the prediction error determines the exact relation between the prediction error effect and the stabilisation welfare effect.

The prediction error problem can be modelled as:

(16) $S_{0}=C_{s}+X_{s}+\beta_{s} w_{0}^{p r e d}$

(17) $S_{1}=S_{0}$

(18) $D=C_{D}+X_{D}+\beta_{D} w$

(19) $S_{1}^{e q}=D^{e q}$

The supply function is split up into a long term supply-function (16), similar to (1), except for the fact that it depends on expected wage rather than the wage itself. The subscript 0 indicates the fact that the prediction has to be made before the market is cleared. (17) is the short term supply function, which is actual at the moment of market-clearance (moment 1). Short-term supply is completely fixed. Students made their choice some years in advance and do not have the possibility to change to another market segment in the short run. Because the prediction error problem focuses on information problems, $X_{S}$ and $X_{D}$ have a slightly different interpretation. They represent the shifts in the supply function and the demand function which were unpredictable at the moment students had to make their choice, due to lack of information at the moment of choice. Due to the well-known rational expectations argument they have therefore also a zero expectation and are uncorrelated with information available at the moment of choice.

Of course, a student can not predict this unpredictable part of the supply and demand-function, which will be called information prediction errors, but also makes an extra prediction error $\varepsilon$, with variance $\sigma_{e}^{2}$. This error can be interpreted as caused by incomplete insight in the functioning of the market. The labour market is very complex, and it is very likely students do not know 'the true model'. Therefore they will make interpretation errors. ${ }^{10}$

10. Most literature on this subject (e.g. Freebairn (1976), Turnovski (1978), and Freebairn and Withers (1979) only recognises this interpretation error and does not include the rational expectations type of prediction error. These two types of prediction error will, however lead to completely different results. 
Formula (20) and (21) give supply and demand function determining the rational expectation wage:

(20) $S=C_{S}+\beta_{s} w_{0}^{r e}$

(21) $D=C_{D}+\beta_{D} w_{0}^{r e}$

The predicted wage is therefore:

(22) $w^{\text {pred }}=\frac{C_{D}-C_{S}}{\beta_{S}-\beta_{D}}+\epsilon=w_{0}^{r e}+\varepsilon=w^{e q}-\frac{X_{D}-X_{S}}{\beta_{s}-\beta_{D}}+\epsilon$

The predicted wage equals the equilibrium wage minus the unpredictable part $\left(\frac{X_{D}-X_{s}}{\beta_{s}-\beta_{D}}\right)$, forming together the rational expectations prediction $\left(w_{0}^{r e}\right)$ plus the interpretation error $\epsilon$.

In the case students use the wrong prediction of (22) supply and demand change into:

(23) $S_{1}=C_{S}+X_{s}+\beta_{s} w_{0}^{\text {pred }}$

$$
\begin{aligned}
& =C_{S}+X_{s}+\beta_{s}\left(w_{0}^{r e}+\epsilon\right) \\
& =C_{s}+X_{s}+\beta_{s} \epsilon+\beta_{s} w_{0}^{r e}
\end{aligned}
$$

(24) $D=C_{D}+X_{D}+\beta_{D} w$

In formula (23) $S_{1}$ is completely fixed, i.e. it does not depend on the wage (w).

Regarding the supply and demand curve with respect to the rational expectation prediction, makes clear that the prediction error model is, except for the information effect, a variant of the stability model of section 2 with:

(25) $X_{S}^{\text {pred }}=X_{S}+\beta_{s} \varepsilon \quad$ with $\quad \sigma_{s}^{2}$ pred $=\sigma_{s}^{2}+\beta_{s}^{2} \cdot \sigma_{e}^{2}$

(26) $X_{D}^{\text {pred }}=X_{D} \quad$ with $\sigma_{D^{\text {pred }}}^{2}=\sigma_{D}^{2}$ account total welfare and only provide emperical and no analytical results. 
Two sources of prediction errors can be distinguished. Firstly, miscalculations of the expected (ex ante) equilibrium wage and unpredictable changes in the supply curve cause the welfare effects comparable to the stabilisation effects caused by a shift in the supply curve (type I errors), while unpredictable changes in the demand curve cause effects similar to welfare effects of fluctuations in the demand curve (type II errors).

Thus, type I errors consist of information errors with regard to supply of labour (e.g. unexpected changes in students preferences) and errors in interpretation, while type II errors refer to information errors with regard to demand (e.g. unknown changes in technology, new investments etc.).

It is more convenient to view prediction errors due to differences in the quantity as caused by predictions errors due to differences in the wage. Formula (27) relates the variance of supply to type I errors and (28) related the variance of demand to type II errors. These two prediction errors with respect to the wage add up to the total wage prediction error (29).

(27) $\sigma_{S}^{2}=\beta_{S}^{2} \sigma_{I}^{2}$ and

(28) $\sigma_{D}^{2}=\beta_{D}^{2} \sigma_{I I}^{2} \quad$ with

(29) $\sigma_{w}^{2}=\sigma_{I}^{2}+\sigma_{I I}^{2}$

The reformulation of the prediction error problem into the stabilisation problem of section 2 makes it possible to use formula's (10), (11) and (12) on the welfare effect of price stabilisation. 
Table 1 and 2 present the welfare-costs of prediction errors of respectively type I and type II:

Table 1: Welfare effects of type I errors ${ }^{11}$

$\left(\sigma_{\pi}^{2}=0\right)$

\section{Stabilisation Allocation Sign}

Student

$-\frac{\beta_{S}^{2}}{-\beta_{D}} \sigma_{I}^{2} \quad-\frac{1}{2} \beta_{S} \sigma_{I}^{2} \quad<0$

Employer

$$
+\frac{1}{2} \frac{\beta_{S}^{2}}{-\beta_{D}} \sigma_{I}^{2}
$$

0

$>0$

Total

$-\frac{1}{2} \frac{\beta_{S}^{2}}{-\beta_{D}} \sigma_{I}^{2} \quad-\frac{1}{2} \beta_{S} \sigma_{I}^{2} \quad<0$

11. Although they explicitly refer to stabilisation theory, Freebairn and Withers (1979) mistakenly assume the redistribution effects of stabilisation to be zero. Therefore their calculations are incorrect. In their formulas the welfare effect of prediction errors for employers is negative instead of positive, and these costs even exceed students costs. 
Table 2: Welfare effects of type II errors

$\left(\sigma_{I}^{2}=0\right)$

$\begin{array}{llll} & \text { Stabilisation } & \text { Allocation } & \text { Sign } \\ \text { Student } & 0 & -\frac{1}{2} \beta_{S} \sigma_{I I}^{2} & <0 \\ \text { Employer } & -\frac{1}{2}\left(-\beta_{D}\right) \sigma_{I I}^{2} & 0 & <0 \\ \text { Total } & -\frac{1}{2}\left(-\beta_{D}\right) \sigma_{I I}^{2} & -\frac{1}{2} \beta_{S} \sigma_{I I}^{2} & <0\end{array}$

The two sources of prediction errors do have completely different consequences for the total welfare, but most of all for the distribution of this welfare. Type I error in which students' prediction error is caused by a miscalculation or misinterpretation of the data that in fact are available or an unexpected change in students preferences, gives rise to a large welfare loss for the student (due to both stabilisation and allocation effects), but is a gain for the employer, since destabilisation of the supply-side is advantageous at the demand side.

Type II error, which is the rational expectation error, which is caused by insufficient data about the demand-side, leads for students only to allocation welfare losses, but leads to stabilisation costs for the employer. Students do not have advantage in this case, like employers in the type I case, because their short run supply-elasticity equals zero. They are not able to react on changes in the demand function ex post.

Type I errors make students to react on labour market changes sometimes more than optimal, while in the case they do not have or use enough information their reaction will be damped. Changes in the labour market situation will not be noticed and therefore do not influence the behaviour.

These results would imply that there is a great difference between welfare effects due to the availability of pure data about future changes in demand and the correct interpretation of these data. Employers as a group have interest in the provision of data on the future labour market situation with respect to demand, but have an opposite interest with respect to the interpretation of these data. Students, on the other hand have interest in both types of information in order to gain from the allocation effect but for the stabilisation effect they only have interest in the interpretation of data available and in changes of the supply curve. 


\section{THE VALUE OF PUBLIC FORECASTS: TWO EMPERICAL EXAMPLES}

In the previous section formulas have been derived that express the welfare cost of prediction errors. Reversely, these costs express possible gains from public forecasts. If government provides a public forecast that reduces the prediction error of the students, there is a gain equal to the difference between the cost with public forecast and without public forecast. If the forecast is perfect this gain is equal to minus the welfare effect in the situation without public forecast.

Several welfare effects have been distinguished. A distinction can be made between information forecasts errors with respect to the demand side (type II) and interpretation forecast errors and information forecast errors with respect to the supply side (type I). Furthermore, the costs have been split into stabilisation effect and allocation effect and into students part and employers part.

In order to get an impression of the extent of the forecast error problem and the relative importance of the distinguished parts, two empirical examples will be presented in this section. Freebairn and Withers (1979) have used two studies of Freeman also to calculate the welfare costs of prediction errors. They have used data and econometric results from Freeman (1975) about the market for lawyers and Freeman (1971) about the market for engineers. Because the calculations of Freebairn and Withers have a more restricted scope and contain some errors ${ }^{12}$, their figures have been recalculated with the formulas of section 4.

Freeman's estimations of supply and demand functions are based on the cobweb-model. In this model it is assumed that students expect that future wage will be equal to the present wage. This behaviour leads to an error of type I, since students in fact are assumed to make an interpretation error. Their error is not caused by lack of data but by the fact that they do not take into account that wages react to supply: their 'model' is too simple.

Based on this assumption Freeman is able to estimate the demand and supply parameters and the variance of the wage forecast error (table $3 a$ ). These figures can be used to calculate the welfare effects of these prediction errors (table $3 \mathrm{~b}$ ). Although the estimated figures relate to a type 1 error, it is interesting, for reason of comparison, to calculate the welfare effects of a type II forecast error of the same extent. These results are presented in table $3 c$.

12. Firstly, they only take into account type I errors. Secondly, as indicated in note nr. 11 , their formula about the distribution of welfare between students and employers is incorrect. To mask the implausible results, the columns representing employers and students' welfare have been exchanged. 
It should be stressed that these empirical results have to be viewed upon with care. Their construction is based upon strong assumptions about the way students form their expectations. Especially the variance of the prediction error might be influenced by this assumption. Therefore, the relative extent of the several effects is more important than their absolute values.

Freebairn and Withers calculate their welfare-measure for a lot of hypothetical situations with respect to interest rate, experience premium salary growth rate and distinguish a nonsubstitution and a substitution case. The welfare effects of these different variants all provide the same picture about the welfare effects of prediction-errors. Their differences can completely be explained by the different assumptions. ${ }^{13}$

For that reason in table 3 only one case is reported. It gives the welfare effects for engineers and lawyers, with respect to their salary of the first 10 years after graduation, under the assumption that graduates are no substitutes for experienced workers, an interest rate of 0 , no experience premium.

13. Except for the difference between substitution and non-substitution. Freebairn and Withers report higher welfare losses in the substitution case, while intuition would predict a reverse result. 
Table 3: Two empirical examples (welfare effects in dollars 1967)

$\beta_{s}$

\begin{tabular}{lrrrrrr} 
3b: type I error & stab & alloc & total & stab & alloc & total \\
\hline Students & -1204 & -2007 & -3211 & -408 & -907 & -1315 \\
Employers & +602 & 0 & +602 & +204 & 0 & +204 \\
Total & -602 & -2007 & -2609 & -204 & -907 & -1111
\end{tabular}

3c: type II error

total

total

Students

Employers

Total

$-2007$

$\begin{array}{rrr}0 & -2007 & -2007 \\ -6690 & 0 & -6690 \\ -6690 & -2007 & -8697\end{array}$

$\begin{array}{rrr}0 & -907 & -907 \\ -4030 & 0 & -4030 \\ -4030 & -907 & -4937\end{array}$

The parameters of the model typically fit into the picture of a specialistic profession. A demand parameter that is more than three times as big as the supply parameter indicates that a small deviation from the equilibrium supply has great influence on the wage. Additional supply has few possibilities to work for the same wage as in the equilibrium situation.

In case of a type I error roughly $66 \%$ of students costs are due to allocation effects. Employers have a small gain in case of this type of forecast error. In case of a type II error, this gain changes into a large loss. Information effects are the same for both types of errors. 


\section{CONCLUSIONS}

Aim of this paper has been to investigate the welfare effects of public labour market forecasts. Since there exists no such thing as a futures labour market, the question was whether it is desirable to provide such a forecast in order to improve the match between education and labour market.

Several distinctions have been made in this paper. First of all, the effects of such a forecast are not the same for employers and students. Secondly, an accurate forecast has two different effects. It stabilises the market and it has an additional allocation effect, i.e. it reduces the amount of students that make a choice which is not optimal with respect to their preferences. Thirdly, two types of forecast errors have to be distinguished: type I errors which consist of unpredictable changes in the supply curve and interpretation errors of students and type II errors which consist of unpredictable changes in demand.

The allocation effect only matters for students. Both types of error lead to an equal loss in welfare due to allocation errors. The stabilisation effect influences both students and employers. In case of a type I error, i.e. in case of changes in the supply function, or in case of interpretation errors, students lose (in expectation) due to this error while employers gain. In total, however, there is a loss. Students' loss is not fully compensated by employers gain. In case of a type II error, i.e. a lack of data with respect to future demand, however, students do not face a stabilisation loss, while employers have a loss. In total, also this welfare effect is always negative.

A cautious conclusion might be that employers, as a group, have more interest in the provision of information about future changes, e.g. the adoption of a new technology, than in the provision of information about the exact consequences of this change with respect to the demand for labour. If the government aims at supporting students in their educational choice, the results of this paper tend to suggest that more attention should be paid to the interpretation of labour market changes and to changes in supply, than to the collection of new, unknown, data. Firstly, students welfare is much more influenced by the first type of information while, secondly, the provision of the other type of information has parallel interests for students and employers, which reduces the need for the government to intervene. 


\section{REFERENCES}

Antonovitz, F. and T. Roe (1986), 'A Theoretical and Emperical Approach to the Value of Information in Risky Markets'. Review of Economics and Statistics 68, pp. 105-114.

Campbell, R.B. and S.J. Turnovski (1985), 'An Analysis of the Stabilizing and Welfare Effects of Intervention in Spot and Futures Markets'. Journal of Public Economics 28, pp. 165-209.

Devletoglou, E.A. (1961) , 'Correct Public Prediction and the Stability of Equilibrium'. Journal of Political Economy 69, pp. 142-161.

Freebairn, J.W. (1976), 'The Value and Distribution of the Benefits of Commodity Price Outlook Information'. The Economic Record 52, pp. 199-212.

Freebairn, J.W. and G.A. Withers (1979), 'Welfare Effects of Salary Forecasts Error in Professional Labour Markets'. The Review of Economics and Statistics 61, pp. 234-241.

Freeman, R.B. (1971), The Market for College-Trained Manpower. Cambridge (Mass.).

Freeman, R.B. (1975), 'Legal "Cobwebs": A Recursive Model of the Market for new Lawyers'. Review of Economics and Statistics 57, pp. 171-179.

Grunberg, E. and F. Modigliani (1954), 'The Predictability of Social Events'. Journal of Political Economy 62, pp. 465-478.

Massel, B.F. (1969), 'Price Stabilization and Welfare'. Quarterly Journal of Economics 83, pp. 284-298.

Oi, W.Y. (1961), 'The Desirability of Price Instability under Perfect Competition'. Econometrica 29 , pp. 58-64.

Samuelson, P.A. (1972), 'The Consumer Does Benefit from Feasible Price Stability'. Quarterly Journal of Economics 86, pp. 476-503.

Smyth, D.J. (1973), 'Effect of Public Price Forecast on Market Price Variation: A Stochastic Cobweb Example'. American Journal of Agricultural Economics 55, pp. 83-88.

Turnovski, S.J. (1974), 'Price Expectations and the Welfare Gains from Price Stabilization'. American Journal of Agricultural Economics 56, pp. 706-716.

Turnovski, S.J. (1978), 'Stabilization Rules and the Benefits from Price Stabilization'. Journal of Public Economics 9, pp. 37-57.

Turnovski, S.J. (1979), 'Future Markets, Private Storage, and Price Stabilization'. Journal of Public Economics 12, pp. 301-327.

Waugh, F.V., (1944), 'Does the Consumer Benefit from Price Instability?' Quarterly Journal of Economics 63, pp. 602-614.

Weller, P. and M. Yano (1987), 'Forward Exchange, Futures Trading, and Spot Price Variability: A General Equilibrium Approach'. Econometrica, 55. pp. 1433-1450. 